\title{
Jukka Kortti, Valtaan ja vastavirtaan. Helsingin yliopiston valtiotieteellinen tiedekunta 75 vuotta
}

Helsinki: SKS kirjat, 2020, 466 s.

Helsingin yliopiston valtiotieteellinen tiedekunta täytti viime vuonna 75 vuotta. Ensimmäinen tiedekuntakokous pidettiin 9.5.1945, kun historiallis-kielitieteellisestä osastosta oli siirretty "yhteiskuntatieteiden aineryhmä", kaksi kansantaloustieteen professuuria sekä finanssiopin ja yleisen valtio-opin professuurit uuteen tiedekuntaan. Samalla myös käytännöllisen filosofian oppituoli siirrettiin osaksi uutta tiedekuntaa. Siten tiedekunta koostui viidestä professorista.

Uusina oppituoleina perustettiin samana vuonna ruotsinkielinen kansantaloustieteen professuuri sekä oppituolit sosiologiaan ja tilastotieteeseen. 1940-luvun lopulla myös sosiaalipolitiikkaan ja poliittiseen historiaan saatiin professuurit ja valtio-oppiin ruotsinkielinen professorin virka. Henkilökohtainen ylimääräinen professori valittiin myös talous- ja sosiaalihistoriaan. Kymmenen vuotta tiedekunnan perustamisen jälkeen nämä professuurit olivat edelleen tiedekunnan ydin.

1950-luvulla tiedekunnan tehtävänä nähtiin virkamiesten kouluttaminen. Päätutkinnoksi oli kaavailtu hallinto-opin kandidaatin tutkintoa, jossa yhdistyivät lainopillisen ja valtiotieteellisen tiedekunnan opintoja. Tutkinto ei kuitenkaan koskaan saavuttanut suosiota ja lakkautettiin vuonna 1959. Sen sijaan sivututkinnoksi ajateltu valtiotieteen kandidaatin tutkinto sai suuren suosion. Sen perustana nähtiin kolme systemaattista yhteiskuntatiedettä, sosiologia, valtio-oppi ja kansantaloustiede. Sosiaalipolitiikka ajateltiin aluksi kansantaloustieteen erityishaaraksi, mutta Heikki Wariksen tultua valituksi aineen ensimmäiseksi professoriksi, oppiaine lähentyi sosiologiaa. Poliittista historiaa taas pidettiin pitkään valtio-opin aputieteenä.

1950-luvun jälkeen tieteenalojen kirjo on laajentunut. Uusina oppiaineina on perustettu sosiaalipsykologia, tiedotusoppi (nykyään viestintä) ja kehitysmaatutkimus (nykyään globaali kehitystutkimus). Lisäksi sosiaalityö on erkaantunut sosiaalipolitiikasta (nykyään yhteiskuntapolitiikka) ja sosiaali- ja kulttuuriantropologia sosiologiasta. Tilastotiede on taas siirretty matemaattis-luonnontieteelliseen tiedekuntaan. Tiedekuntaan on myös liitetty Svenska social- och kommunalhögskolan, ja sen alaisuudessa toimii neljä tutkimusyksikköä: Kuluttajatutkimuskeskus, Kriminologian ja oikeuspolitiikan instituutti, Eurooppa-tutkimuksen keskus ja Yhteiskuntadatatieteen keskus. Täysiä professoreja on yli 40, ja kun mukaan lasketaan yliopistonlehtorit ja erilaiset tutkijat, tutkimushenkilöstön määrä on yli 400. Kauas on tultu alun viidestä professorista!

Kehitystä kuvaamaan ilmestyi viime vuonna tiedekunnan tilaama Jukka Kortin kirjoittama 75-vuotishistoriikki. On kiitettävää, että tiedekunta on halunnut tallentaa omaa historiaansa, onhan se suomalaisen yhteiskuntatieteellisen tutkimuksen kehto. Kirja onkin hyödyllistä luettavaa yhteiskuntatieteistä kiinnostuneille, ei pelkästään valtiotieteellisen tiedekunnan kasvateille. Kun Kortti on laaja-alaisesti paneutunut aiheeseen, kirjoittaa sujuvasti ja nostaa esiin tärkeitä yksityiskohtia kehityksestä, lukija löytää kirjasta paljon mielenkiintoista.

Kortti jaksottaa tiedekunnan historian kolmeen vaiheeseen: 
1. Valtiotieteet ja yhteiskunta (1945-1967). Ajanjakso, jolloin korostui tiedekunnan, erityisesti sosiaalitieteiden rooli, suomalaisen (hyvinvointi)valtion ja yhteiskunnan rakentamisessa. Tiedekunnan syntyhistorian ohessa luvussa käsitellään yleistä 1960-luvun korkeakoulupolitiikkaa sekä tiedekunnan haasteita kasvavan opiskelijamäärän paineessa. Tutkimuksen ja opetuksen muuttumisessa Kortti painottaa yhteiskuntatieteiden "amerikanisoitumista".

2. Valtiotieteet ja politiikka (1968-1979). Ajanjakso, jolloin politiikka hallitsi tiedekunnan toimintaa. Luvussa painottuvat yliopistoradikalismi, yliopistohallinnonuudistustaistelu (yleinen ja yhtäläinen äänioikeus opiskelijoista professoreihin), taistelu tutkintovaatimuksista, Filosofisten ja yhteiskuntatieteellisten tutkintojen uudistamisen toimikunnan (FYTT) työskentely sekä tutkimuksen politisoituminen. Kortti käy läpi niin TANDEM-DETA taiston kuin muitakin ajan tutkimuksellisia kiistakysymyksiä.

3. Valtiotieteet ja markkinat (1980-2020). Ajanjakso, jolloin talous on enenevästi määrittänyt opetusta. Kortti kuvailee tulosjohtamisen kehitystä, uusien oppiaineiden ja uusien opintokokonaisuuksien syntyä, tutkimuksen (ja opetuksen) kansainvälistymistä, virkarakenteen muuttumista, uudenlaista opetukseen panostamista ja huomion kiinnittämistä tasa-arvokysymyksiin. Lopuksi hän tarkastelee tiedekunnan hallinnon muutosta, kun vanhoista tieteenalalaitoksista siirryttiin kahteen suurlaitokseen vuonna 2010 ja lopuksi laitoksettomaan tiedekuntaan vuoden 2018 alusta.

Historian läpi kulkee myös yleisiä teemoja, kuten korkeakoulupolitiikka, kansainvälistyminen ja yhteiskuntatieteiden määrittyminen. Samaten virkanimitykset ja niistä käydyt kamppailut nousevat esiin kaikissa ajanjaksoissa. Erityishuomion saavat muutamat professorinimitykset: ensimmäisessä ajanjaksossa käytännöllinen filosofia, poliittinen historia ja sosiaalipolitiikka; toisessa käytännöllinen filosofia ja tiedotusopin lahjoitusprofessuuri; kolmannessa sosiologian professuurin kielitaitovaatimukset. Virkojen täyttöprosessit asiantuntijalausuntoineen ovat jälkikäteen masentavaa luettavaa. Kuka on pätevä, kuka epäpätevä, on ollut usein elämää suurempi kysymys. Kuten Henri Kissinger aikoinaan totesi, akateemiset taistelut ovat usein verisiä, koska panokset ovat niin pieniä.

Teoksen mielenkiintoisuudesta huolimatta siinä on neljä pääongelmaa. Vaikka sivumääriin ei ole syytä kiinnittää liikaa huomiota, niiden perusteella voisi ajatella, että tärkein vaihe tiedekunnan historiassa ajoittuu vuosiin 1968-1979. Tämä 12 vuoden ajanjakso saa huomiota 107 sivun verran, kun taas kolmannen vaiheen 41 vuotta käsitellään 140 sivua. Periodisoinnin ja painotuksen olisi voinut tehdä toisinkin.

Olihan 1970-luku poliittisesti villiä aikaa tiedekunnassa ja jotkut saivat siitä traumojakin, useimmat kuitenkaan eivät. Kuohunnasta huolimatta tiedekunnan opetuksen suuri linja pysyi ennallaan. Vaikka tutkintovaatimuksiin otettiin marxilaisia teoksia, eivät ne oleellisesti muuttaneet opetusta. Kun opiskelijat halusivat Leninin teoksia valtio-opin tutkintovaatimuksiin vuonna 1971, laitoksen johtaja Jan-Magnus Jansson totesi vain, että Leninin teos Valtio ja vallankumous sopii hyvin luettavaksi, olihan se klassikko.

En ole varma, kuinka mielekästä on käyttää monta sivua kuvaamaan Akateemisen sosialistiseuran toimintaa, taistelua mies ja ääni- uudistuksesta, tutkintovaatimuksista käytyjä kiistoja ja 
FYTTin sinänsä aikaa vienyttä suunnittelutyötä. Ei näistä paljon mitään jäänyt käteen, vaikka meille marxismista kiinnostuneille nuorille tutkijoille pääomalogiikan saloihin tutustuminen tarjosi kyllä hyvää harjaantumista teoreettiseen ajatteluun.

Toinen ongelma on, että teoksessa painottuvat mediaseksikkäät tapahtumat, mutta niiden seuraukset jäävät usein käsittelemättä. Mitkä olivat esimerkiksi kiisteltyjen virkanimitysten seuraukset? Toinen esimerkki on Suomen akatemian vuosina 1973-1976 rahoittamat suomalaista demokratiaa ja tasa-arvoisuutta tutkivat kaksi suurprojektia, joita Kortti käsittelee 1970-luvun poliittisten kamppailujen ilmentymänä. Sosiologien marxilaisvaikutteinen TANDEM-projekti saa paljon enemmän huomiota, vaikka sen myöhempi merkitys sosiologialle on ollut vähäinen verrattuna esimerkiksi Erik Allardtin samanaikaisen vertailevan sosiologian tutkimusryhmän perintöön. Kirjassa vähemmän huomiota saaneen, Ilkka Heiskasen johtaman valtio-opin DETA-projektin merkitys sen sijaan oli tieteenalalle tärkeä. Sen mukana suomalaiseen politiikan tutkimukseen levisi muun muassa policy-analyyttinen tutkimus, mikä vaikutti myös muiden maamme valtio-opin yksiköiden toimintaan.

Opetuksen osalta FYTT on myös esimerkki seurausten käsittelyn puutteesta. Sen tuloksena syntyi vuoden 1978 tutkintojärjestelmä, jota alettiin soveltaa syksyllä 1980. Tiedekunnan pyrkimyksenä oli laittaa vanhat tutkintovaatimukset vain uudelle kielelle, ja monet ajattelivat, ettei uudistus muuttanut paljoakaan vanhoja käytäntöjä (s. 211-212). Sillä oli kuitenkin tarkoittamattomia seurauksia, joita Kortti ei käsittele. Uudet koulutusohjelmat olivat pääainekeskeisimpiä kuin vanhat ohjelmat. Ne tekivät myös mahdolliseksi eriyttää pääaine- ja sivuaineopintoja toisistaan, mikä vähensi eri oppiaineiden opiskelijoiden keskinäistä kanssakäymistä. Sama tapahtui jatkokoulutusuudistuksessa vuosina 1987-1989. Sen jälkeen ei enää vaadittu syventäviä opintoja (laudaturia) toisessa aineessa, vaan laitokset saattoivat laatia jatkokoulutettaville oman 35 opintoviikon opetuspaketin. Oma lukunsa on, että vuonna 1980 uudet opiskelijat alettiin valita pääaineisiin.

Kolmas ongelma on tieteenalojen asema historiikissa. Kortti on tietoisesti rajannut tutkimuksensa tiedekuntatasolle ja korostaa, ettei tutkimus ole tieteenalojen historiaa, vaikka oppiaineita ja laitoksia ajoittain tarkastellaankin. Niiden käsittely on riippunut erilaisista tekijöistä. Esimerkiksi sosiologian rooli on korostunut, varsinkin ensimmäisessä ajanjaksossa, koska "sosiologit määrittelivät, mistä ja miten puhuttiin" (s. 90). Toisaalta pienet tieteenalat, sosiaalipsykologia, poliittinen historia ja käytännöllinen filosofia, ovat saaneet kokoaan suuremman roolin "aktiivisten henkilöiden" tai "laajaa yleistä merkitystä koskevien rajanvetojen" johdosta (s. 16).

En pysty näkemään tämän argumentaation logiikkaa. Tiedekunnan historia on paljolti sen tieteenalojen historiaa. Kehityksen kuvaaminen tiedekunnan tasolla on tärkeää, mutta tiedekunta on pääasiassa hallinnollinen yksikkö, joka säätelee tieteenaloja, allokoi resursseja ja organisoi opetusta. Samalla tieteenalat levittäytyvät tiedekunnan ulkopuolelle monin lonkeroin. Suurimmalle osalle tutkijoista ja opettajista yhteydet oman alan tutkimusjärjestöihin ja kollegoihin maailmanlaajuisesti ovat tieteellisesti tärkeämpiä kuin tiedekunta.

Politiikan tutkijan silmään pistää, että valtio-oppi on saanut historiikissa suhteellisen rajoittuneen roolin, vaikka se on ollut keskeisessä asemassa tiedekunnassa koko sen olemassaolon ajan. Kirjassa on myös pieniä virheitä tai osatotuuksia tieteenalasta. Lähtemättä luettelemaan kaikkia ongelmallisia kohtia nostan esiin muutaman. 
Kortti on tulkinnut yksipuolisesti politiikan tutkimuksen muutosta 1950- ja 1960-luvuilla kirjoittaessaan, että "Teljon loogisen positivismin tiukka, luonnontieteistä vaikutteita ottanut skientismi korvasi aiemmat Brotheruksen ja Ruudun sosiologis-historialliset, Allgemeine Staatslehre -hengestä nousseet perinteet" (s. 140). Jussi Teljo ei kuitenkaan edustanut loogista positivismia, vaan pikemmin hän oli kiinnostunut klassisesta eurooppalaisesta poliittisesta sosiologiasta (eliittiteoreetikot), vaikkakin halusi opiskelijoiden tutustuvan myös uuteen amerikkalaiseen empiiriseen politiikan tutkimukseen. Käyttäytymistieteellinen lähestymistapa ei syrjäyttänyt vanhoja tutkimusperinteitä, vaan tuli niiden rinnalle.

Kolmannen ajanjakson käsittelyssä taas valtio-opin rooli tiedekunnan uudistusten alullepanijana ja toteuttajana on suurelta osin jätetty huomioimatta. Laitoksen yhteyteen perustettiin erillinen hallinnollisten tietojärjestelmien liitännäisohjelma vuonna 1988. Uusista monitieteisistä sivuainekokonaisuuksista Kansainvälisten tehtävien opintokokonaisuutta (1995) ja EU- opintokokonaisuutta (2001) johdettiin valtio-opin laitokselta käsin, johon kokonaisuuksista vastaavat tutkimuspäälliköt olivat sijoitettuina. Vuonna 1998 aloitettiin laitoksen aloitteesta Johtamisen sivuainekokonaisuus (JOS), joka käytännössä oli hallinto-opin linjan projekti. Valtio-opin osuutta näissä uudistuksissa Kortti ei huomioi, kuten ei sitäkään, että laitos valittiin valtakunnalliseksi koulutuksen laatuyksiköksi kahdesti sekä vuosina 2002-2005 että 2006-2009.

Kuvaava esimerkki on myös viittaus EU-opetuksen alkuun tiedekunnassa. Kortti toteaa, että Euroopan yhdentyminen näkyi 1990-luvun alussa tiedekunnan opetuksessa ja antaa esimerkkinä vuonna 1992 poliittisessa historiassa järjestetyn luentosarja "Eurooppa - osiensa summa" (s. 294). Mitenkään väheksymättä luentosarjaa, olisi ehkä ollut hyvä mainita, että valtio-opissa EU-opetusta on ollut säännöllisesti vuodesta 1991 lähtien, osittain jo 1980-luvulla, kun opinnoissa käsiteltiin alueellista integraatiota. Unohtaa ei sovi myöskään 1990-luvun loppupuolen Tuomo Martikaisen johtamaa European Policy-Making -ohjelmaa, johon liittyi valtio-opissa laaja EU-opetuksen paketti, jonka yhteydessä monet opiskelijat kirjoittivat pro gradunsa. Ohjelmassa työskentelivät esimerkiksi Olli Rehn ja Teija Tiilikainen, ja sen perustalta syntyi tiedekunnan EU-opintokokonaisuus.

Mistä johtuu sosiaalitieteiden roolin korostuminen teoksessa? Ehkä tämä on seurausta teoksen "historiatoimikunnan" kokoonpanosta ja haastatelluista henkilöistä. Historiikkia varten on haastateltu 21 henkilöä, joista yli puolet olivat sosiaalitieteilijöitä ja vain kaksi valtio-oppineita. Asettamatta kyseenalaiseksi entisen kansainvälisen politiikan professorin tai avoimen korkeakoulun yliopistonopettajan asiantuntemusta, heidän näkökulmansa valtio-opin laitokseen on kuitenkin rajattu. 1960-luvun lopun ja 1970-luvun painottuminenkin teoksessa saattaa johtua samasta syystä. Suurin osa haastatelluista aloitti tutkimusuransa tuona aikana. Haastattelut ovatkin ongelmallisia, jos niihin ei sovella lähdekritiikkiä. Nyt Kortti turhan usein luottaa haastateltaviensa tulkintoihin.

Juhlakirjoissa on se ongelma, että ne pitää saada valmiiksi määräaikaan mennessä. Kortin teoksen neljäs ongelma on, että työ on jäänyt monessa mielessä kesken. Kolmannessa ajanjaksossakin nostetaan esiin "kamppailuja ja rajanvetoja", kuten kehitysmaatutkimuksen riitaisa alkuvaihe, sukupuolisyrjintä valtio-opin laitoksella ja kamppailu tiedekunnan hallintorakenteesta vuonna 2009. Monet asiat kuitenkin vain sivutaan lyhyesti.

Kamppailu laitosrakenteesta saa paljon huomiota, mutta yksi sen tärkeä seuraus jää käsittelemättä. Uudistuksessa hävitettiin vanhojen laitosten johtoryhmät, mikä osaltaan tuhosi 
yliopistodemokratiaa. Olisi ollut myös mielenkiintoista tietää enemmän tieteenalojen sisäisistä kiistoista. Valtio-opissa oli esimerkiksi hyvin tulehtunut tilanne 2000-luvun alussa, kun hallinnon ja organisaatioiden tutkimuksen linjan opettajat olisivat halunneet irtaantua omaksi tieteenalaksi. Muut oppiaineen opettajat eivät tähän kuitenkaan suostuneet. Olivatko sosiaalityön irtaantuminen sosiaalipolitiikasta ja antropologian sosiologiasta sopuisampia prosesseja?

Historiansa aikana tiedekunta on kokenut monia muutoksia. Koko on yksi muuttuja. Kun itse aloin työskennellä valtio-opin laitoksella 1960-luvun lopussa, tiedekunta oli lintukoto, jossa ihmiset tunsivat toisensa. Myös nimipolitiikan analysointi kertoisi yhteiskunnan ja tiedekunnan muuttumisesta. Kortti käsittelee tiedotusopin muuttamista viestinnäksi (s. 249-250), mutta ei kiinnitä huomiota sosiaalipolitiikan muuttamiseen yhteiskuntapolitiikaksi, eikä kansan poistamista kansantaloustieteestä (kirjan ilmestymisen jälkeen kehitysmaatutkimuskin näkyy muuttuneen globaaliksi kehitystutkimukseksi). Kun tiedekunnan syntyessä korostettiin virkamiesten kouluttamista, nykyään tieteenalat sanovat kouluttavansa asiantuntijoita. Mutta mitä tämä käytännössä tarkoittaa? Sitä paitsi, jos sosiologit aikoinaan määrittelivät, mistä ja miten puhuttiin, tällä hetkellä sen tekevät taloustieteilijät ja valtio-oppineet. Lukija jää kaipaamaan yhteenvetolukua, jossa pohdittaisiin tiedekunnan muutosta sen historian valossa.

\section{KIRJOITTAJATIEDOT}

\section{ERKKI BERNDTSON}

VTL, vapaa tutkija

Yleisen valtio-opin lehtori (eläkkeellä)

erkki.berndtson@gmail.com 